\title{
Antibacterial activity of vegetal extracts against serovars of Salmonella
}

\author{
Atividade antibacteriana de extratos vegetais sobre sorovares de Salmonella
}

\author{
Daiane Voss-Rech ${ }^{\mathrm{I}, \mathrm{II}^{*}}$ Cátia Silene Klein ${ }^{\mathrm{I}}$ Vânia Helena Techio ${ }^{\mathrm{III}}$ \\ Gerson Neudi Scheuermann ${ }^{\text {I }}$ Gilberto Rech $^{\text {II }}$ Laurimar Fiorentin ${ }^{\mathrm{I}, \mathrm{IV}}$
}

\begin{abstract}
In vitro antibacterial activity of 21 hydroethanolic vegetal extracts was assessed against 20 serovars of Salmonella. Regarding the tested extracts, $85.7 \%$ of them presented antibacterial activity. The six active extracts which showed activity on the largest number of serovars and the extract of Eucalyptus sp. were submitted to the determination of Minimum Inhibitory Concentration (MIC) and Minimum Bactericidal Concentration (MBC). Of these, six extracts showed bacteriostatic and bactericidal activity with MIC and MBC for Punica granatum (pomegranate) from 20 and $60 \mathrm{mg} \mathrm{mL}^{-1}$, for Eugenia jambolana (rose apple) from 40 and $240 \mathrm{mg} \mathrm{mL}^{-1}$, Eugenia uniflora (surinam cherry) from 80 and $240 \mathrm{mg} \mathrm{mL}^{-1}$, Caryophyllus aromaticus (clove) from 10 and $60 \mathrm{mg} \mathrm{mL} \mathrm{L}^{-1}$, Psidium araca from 30 and $320 \mathrm{mg} \mathrm{mL}^{-1}$ and Eucalyptus sp. from 40 and $160 \mathrm{mg} \mathrm{mL}^{-1}$. Achyrocline satureioides (macela) presented only bacteriostatic potential and MIC from $160 \mathrm{mg}$ $m L^{-1}$. Caryophyllus aromaticus, Eucalyptus sp., and Psidium araca presented the best results for bactericidal activity, inhibiting, respectively, $84.2 \%, 42.1 \%$, and $17.6 \%$ of Salmonella's serovars. The activity of each extract varied for different serovars; $\boldsymbol{S}$. London presented resistance to the six extracts in MBC, while S. Pullorum was the most susceptible serovar.
\end{abstract}

Key words: antibacterial activity, vegetal extracts, Salmonella.

\section{RESUMO}

A atividade antibacteriana de 21 extratos hidroetanólicos vegetais foi avaliada in vitro frente a 20 sorovares de Salmonella. Dos extratos testados, 85,7\% apresentaram atividade antibacteriana. Os seis extratos que evidenciaram atividade sobre o maior número de sorovares $e$
Eucalyptus sp. foram submetidos à determinação da Concentração Inibitória Mínima (CIM) e Concentração Bactericida Mínima (CBM). Destes, seis extratos apresentaram atividade bacteriostática e bactericida com MIC para Punica granatum (romã) a partir de 20 e $60 \mathrm{mg} \mathrm{mL}^{-1}$, Eugenia jambolana (jambolão) de 40 e $240 \mathrm{mg}^{\mathrm{mL}} \mathrm{L}^{-1}$, Eugenia uniflora (pitanga) de 80 e 240mg $\mathrm{mL}^{-1}$, Caryophyllus aromaticus (cravo) de 10 e $60 \mathrm{mg} \mathrm{mL}^{-1}$, Psidium araca (araçá) 30 e $320 \mathrm{mg}$ $\mathrm{mL}^{-1}$ e Eucalyptus sp. (eucalipto) de 40 e $160 \mathrm{mg} \mathrm{mL}^{-1}$. Achyrocline satureioides (macela) apresentou apenas atividade bacteriostática e MIC a partir de $160 \mathrm{mg}^{\mathrm{mL}} \mathrm{L}^{-1}$. Caryophyllus aromaticus, Eucalyptus sp. e Psidium araca apresentaram os melhores resultados para a atividade bactericida, inativando, respectivamente, $84,21 \%, 42,1 \%$ e $17,64 \%$ dos sorovares de Salmonella. A atividade de cada extrato variou para diferentes sorovares. Nenhum dos seis extratos avaliados evidenciou atividade bactericida frente a S. London, enquanto S. Pullorum foi o sorovar mais sensível.

Palavras-chave: atividade antibacteriana, extratos vegetais, Salmonella.

\section{INTRODUCTION}

The last century was marked by efforts to search for compounds with therapeutic properties, giving the scientific community numerous substances that showed antimicrobial activity (EMEA 1999). The specific and rapid action of such antibiotics has promoted considerable progress, since they surpassed previously known drugs. However, the majority of

IEmpresa Brasileira de Pesquisa Agropecuária (Embrapa) Suínos e Aves, Br 153, Km 110, Vila Tamanduá, 89700-000, Concórdia, SC, Brasil. E-mail: daiane@cnpsa.embrapa.br. *Autor para correspondência.

"Universidade do Contestado (UnC), Concórdia, SC, Brasil.

IIIDepartamento de Biologia, Universidade Federal de Lavras (UFLA), Lavras, MG, Brasil.

${ }^{\mathrm{IV}}$ In memorian. 
antibiotics act as bacteria-selective agents, which increases bacterial resistance through genetic mutation.

Currently, there is concern about bacterial resistance to antibiotics. This concern is based on the gradual reduction of the number of efficient antibiotics, and on the toxic effects of the antibiotic's residues in animal products (CHAGAS, 2004; TRABULSI \& ALTHERTHUM, 2005). In this context, there has been increased interest in studies searching for vegetal compounds that present antibacterial activity.

Among the numerous pathogenic bacteria with an antimicrobial resistant profile, Salmonella are important agents that cause foodborne diseases worldwide. Currently, there are 2,501 known serovars of Salmonella, some more restricted and adapted to a unique host, and others capable of infecting several species (FRANCO et al., 2005; TRABULSI \& ALTHERTHUM, 2005).

The large numbers of serovars, the adaptation to several hosts, and the ability to acquire and transmit alleles of resistance to antimicrobials are some of the factors that contribute to the pathogenicity of Salmonella (TRABULSI \& ALTHERTHUM, 2005). This picture requires control of the use of antimicrobials and research into new antimicrobials, with focus on human health and to reduce losses in animal production. Some studies (SOUZA et al., 2000;
AVANCINI et al., 2000; CIRAJ et al., 2001; LOGUERCIO et al., 2005) have demonstrated the potential use of plant extracts with bactericidal or bacteriostatic for Salmonella. In the search for alternatives to conventional antibacterials, new plant species should be tested in order to identify which are more efficient as antimicrobial agents. The use of vegetal extracts represents a possibility which seems to be economically viable and ecologically safe for Salmonella control. The objective of this study was to evaluate in vitro the antimicrobial activity of some vegetal extracts against Salmonella serovars.

\section{MATERIAL AND METHODS}

Material sampling and preparation of vegetal extracts The vegetal species used (Table 1) were collected in Concórdia - Santa Catarina State, Brazil, except Caryophyllus aromaticus, which was acquired in a commercial establishment. Sampling procedure was performed in the morning between 7 and $8 \mathrm{~h}$, during March and May of 2007. All the sampled plants were located away from any chemical contaminants. Voucher specimens were prepared and kept in the Herbarium of the Universidade do Contestado-UnC, ConcórdiaSanta Catarina. The identification of the plants was carried out from the analysis of morphological

Table 1 - Frequency of Salmonella serovars inhibited by plants extracts.

\begin{tabular}{|c|c|c|c|c|}
\hline Vegetal species & Common Names & Family & Used portion & $\begin{array}{c}\text { Inhibited } \\
\text { serovars }(\%)\end{array}$ \\
\hline Punica granatum $\mathrm{L}$. & Pomegranate & Lythraceae & Fruit & 100 \\
\hline Eugenia jambolana Lam. & Rose apple & Myrtaceae & Leaf & 90 \\
\hline Eugenia uniflora $\mathrm{L}$. & Surinam cherry & Myrtaceae & Leaf & 90 \\
\hline Caryophyllus aromaticus $\mathrm{L}$. & Clove & Myrtaceae & Package content & 75 \\
\hline Psidium araca Raddi & Araçá & Myrtaceae & Leaf & 75 \\
\hline Achyrocline satureioides (Lam.) & Macela & Asteraceae & Flowered aerial portion & 70 \\
\hline Rosmarinus officinalis L. & Rosemary & Lamiaceae & Leaf & 62.5 \\
\hline Cynara scolymus L. & Artichoke & Asteraceae & Leaf & 55 \\
\hline Salvia officinalis L. & Common sage & Lamiacae & Leaf & 45 \\
\hline Laurus nobilis L. & Sweet bay & Lauraceae & Leaf & 44.4 \\
\hline Bidens pilosa $\mathrm{L}$. & Hairy beggarticks & Asteraceae & Flowered aerial portion & 42.1 \\
\hline Baccharis trimera (Less.) DC & Carqueja & Asteraceae & Aerial portion & 30 \\
\hline Plectranthus barbatus Andrews & Forskohlii & Asteraceae & Leaf & 15.8 \\
\hline Sonchus oleraceus L. & Annual sowthistle & Lamiacae & Flowered aerial portion & 10 \\
\hline Mikania glomerata Spreng. & Guaco & Asteraceae & Leaf & 10 \\
\hline Taraxacum officinale F.H. Wigg. & Common dandelion & Asteraceae & Flowered aerial portion & 5 \\
\hline Emilia sonchifolia (L.) DC & Cupid's shaving-brush & Asteraceae & Flowered aerial portion & 5 \\
\hline Plantago australis Lam. & Mexican plantain & Plantaginaceae & Leaf & 5 \\
\hline Maytenus ilicifolia (Schrad.) Planch. & Holy-thorn & Celastraceae & Leaf & 0 \\
\hline Aloe arborescens Mill. & Candelabra aloe & Liliaceae & Leaf & 0 \\
\hline Malva sylvestris L. & Common mallow & Malvaceae & Leaf & 0 \\
\hline
\end{tabular}

Ciência Rural, v.41, n.2, fev, 2011. 
characters and identification keys (BREMER et al., 2000; LORENZI \& MATOS, 2002; THE ANGIOSPERM PHYLOGENY GROUP, 2003; SOUZA\& LORENZI, 2005).

Sampled fresh vegetal portions were cleaned with a distilled-water wet paper towel and submitted to mechanical grinding. In order to obtain hydroethanolic extracts, a one-week extraction was performed using $1 \mathrm{~g}$ of plant per $4 \mathrm{~mL}$ of ethanol $(80 \%)$. The solution was submitted to centrifugation (5 minutes at $540 \mathrm{~g}$ ), in order to remove suspended particles, then further incubated at $50^{\circ} \mathrm{C}$ for the evaporation of ethanol. The residual material was re-suspended in ethanol (80\%) in a way that each $\mathrm{mL}$ contained the extract equivalent of $5 \mathrm{~g}$ of the plant. This concentrate was centrifuged at $13000 \mathrm{~g}$ and kept under refrigeration (VIEIRA et al., 2005; COELHO et al., 2003).

In vitro antibacterial activity evaluation.

Twenty serovars of Salmonella from the Animal Health Laboratory of Embrapa Swine \& Poultry in Concórdia, Santa Catarina State, Brazil were used (Table 2). The selecting tests for the extracts were performed by well diffusion method on plates (GROOVE \& RANDALL, 1995). Aliquots of $0.1 \mathrm{~mL}$ containing approximately $10^{6}$ colony-forming units (CFU) $\mathrm{mL}^{-1}$ were spread with sterile swabs on the surface of plates with $10 \mathrm{~cm}$ diameter containing nutrient agar. On each plate, six wells of $6 \mathrm{~mm}$ diameter were prepared. Each well received $40 \mu \mathrm{L}$ of extract, diluted in a 1:5 ratio in $80 \%$ ethanol. This amount of extract corresponds to the extract obtained from $40 \mathrm{mg}$ of plant in its natural form. All tests were performed in duplicate. Nalidixic acid and $80 \%$ ethanol were used for positive and negative controls, respectively. The plates were kept in the refrigerator for one hour for diffusion of the extracts, and incubated for 18 to $24 \mathrm{~h}$ at $37^{\circ} \mathrm{C}$. Antibacterial activity was evaluated through reading of the growth inhibition zone.

The six extracts that showed activity in at least $70 \%$ of the serovars in the well diffusion method were submitted to the dilution technique for determining quantitatively the Minimum Inhibitory Concentration (MIC). Based on the results obtained in this study with the Myrtaceae family, the extract of Eucalyptus sp. was also included in the determination of MIC.

Table 2 - Minimum Inhibitory Concentration (MIC) and Minimum Bactericidal Concentration (MBC) of vegetal extracts against serovars of Salmonella

\begin{tabular}{|c|c|c|c|c|c|c|c|}
\hline \multirow[t]{2}{*}{ Salmonella Serovars } & $\begin{array}{l}\text { Achyrocline } \\
\text { satureioides }\end{array}$ & $\begin{array}{c}\text { Caryophyllus } \\
\text { aromaticus }\end{array}$ & $\begin{array}{c}\text { Eucaliptus } \\
\text { sp. }\end{array}$ & $\begin{array}{c}\text { Eugenia } \\
\text { jambolana }\end{array}$ & $\begin{array}{l}\text { Eugenia } \\
\text { uniflora }\end{array}$ & $\begin{array}{l}\text { Psidium } \\
\text { araca }\end{array}$ & $\begin{array}{c}\text { Punica } \\
\text { granatum }\end{array}$ \\
\hline & \multicolumn{7}{|c|}{ - } \\
\hline S. Agona & $240 />\mathrm{LD}$ & $40 / 160$ & $120 />\mathrm{LD}$ & $160 />\mathrm{LD}$ & $240 />\mathrm{LD}$ & $80 / \mathrm{NP}$ & $40 />\mathrm{LD}$ \\
\hline S. Anatum & $>\mathrm{LD} />\mathrm{LD}$ & $40 / 120$ & $80 / 320$ & $160 />\mathrm{LD}$ & $160 />\mathrm{LD}$ & $80 />\mathrm{LD}$ & $80 />\mathrm{LD}$ \\
\hline S. Cerro & $>\mathrm{LD} />\mathrm{LD}$ & $40 / 120$ & $80 / 320$ & $80 />\mathrm{LD}$ & $240 />\mathrm{LD}$ & $80 />\mathrm{LD}$ & $80 />\mathrm{LD}$ \\
\hline S. Choleraesuis & $\mathrm{NP} />\mathrm{LD}$ & $30 / 120$ & $80 />\mathrm{LD}$ & $120 />\mathrm{LD}$ & $160 />\mathrm{LD}$ & $30 />\mathrm{LD}$ & $\mathrm{NP} />\mathrm{LD}$ \\
\hline S. Cubana & $160 />\mathrm{LD}$ & $20 / 60$ & $60 />\mathrm{LD}$ & $80 />\mathrm{LD}$ & $120 />\mathrm{LD}$ & $40 />\mathrm{LD}$ & $20 / 160$ \\
\hline S. Derby & $320 />\mathrm{LD}$ & $60 / 80$ & $60 / 320$ & $160 />\mathrm{LD}$ & $80 />\mathrm{LD}$ & $80 / 320$ & $80 />\mathrm{LD}$ \\
\hline S. Enteritidis & $240 />\mathrm{LD}$ & $40 />\mathrm{LD}$ & $80 />\mathrm{LD}$ & $120 />\mathrm{LD}$ & $160 />\mathrm{LD}$ & $80 / 320$ & $80 />\mathrm{LD}$ \\
\hline S. Give & $320 />\mathrm{LD}$ & $30 / 60$ & $40 / 160$ & $40 />\mathrm{LD}$ & $120 />\mathrm{LD}$ & $60 />\mathrm{LD}$ & $80 />\mathrm{LD}$ \\
\hline S. Heidelberg & $240 />\mathrm{LD}$ & $30 / 40-60$ & $160 />\mathrm{LD}$ & $80 />\mathrm{LD}$ & $120 />\mathrm{LD}$ & $60 />\mathrm{LD}$ & $80 />\mathrm{LD}$ \\
\hline S. Infantis & $>\mathrm{LD} />\mathrm{LD}$ & $40 / 40-60$ & $120 />\mathrm{LD}$ & $160 />\mathrm{LD}$ & $240 />\mathrm{LD}$ & $80 / \mathrm{NP}$ & $240 />\mathrm{LD}$ \\
\hline S. London & $320 />\mathrm{LD}$ & $40 />\mathrm{LD}$ & $120 />\mathrm{LD}$ & $160 />\mathrm{LD}$ & $>\mathrm{LD} />\mathrm{LD}$ & $80 />\mathrm{LD}$ & $120 />\mathrm{LD}$ \\
\hline S. Manhattan & $>\mathrm{LD} />\mathrm{LD}$ & $40 / 60$ & $60 / 160$ & $160 />\mathrm{LD}$ & $160 />\mathrm{LD}$ & $80 / 320$ & $80 />\mathrm{LD}$ \\
\hline S. Meleagridis & $320 />\mathrm{LD}$ & $30 />\mathrm{LD}$ & $80 / 320$ & $160 />\mathrm{LD}$ & $240 />\mathrm{LD}$ & $80 />\mathrm{LD}$ & $60 />\mathrm{LD}$ \\
\hline S. Montevideo & $>\mathrm{LD} />\mathrm{LD}$ & $40 / 60$ & $80 />\mathrm{LD}$ & $160 />\mathrm{LD}$ & $320 />\mathrm{LD}$ & $80 />\mathrm{LD}$ & $120 />\mathrm{LD}$ \\
\hline S. Newport & $320 />\mathrm{LD}$ & $40 / 320$ & $40 />\mathrm{LD}$ & $160 />\mathrm{LD}$ & $160 />\mathrm{LD}$ & $40 />\mathrm{LD}$ & $80 />\mathrm{LD}$ \\
\hline S. Oranienburg & $>\mathrm{LD} />\mathrm{LD}$ & $60 / 120$ & $160>\mathrm{LD}$ & $160 />\mathrm{LD}$ & $160 />\mathrm{LD}$ & $160 />\mathrm{LD}$ & $80 />\mathrm{LD}$ \\
\hline S. Panama & $160 />\mathrm{LD}$ & $30 / 120$ & $60 / 320$ & $160 />\mathrm{LD}$ & $160 />\mathrm{LD}$ & $80 />\mathrm{LD}$ & $40 />\mathrm{LD}$ \\
\hline S. Pullorum & $320 />\mathrm{LD}$ & $10 / 80$ & $40 / 320$ & $40 / 240$ & $120 / 240$ & $80 />\mathrm{LD}$ & $40 / 60$ \\
\hline S. Typhimurium & $>\mathrm{LD} />\mathrm{LD}$ & $60 / 80$ & $160 />\mathrm{LD}$ & $320 />\mathrm{LD}$ & $>\mathrm{LD} />\mathrm{LD}$ & $80 />\mathrm{LD}$ & $320 />\mathrm{LD}$ \\
\hline
\end{tabular}

LD: Limit of detection $\left(320 \mathrm{mg} \mathrm{mL}^{-1}\right)$; NP: Not performed. 
Determination of the Minimum Inhibitory

Concentration (MIC) and the Minimum Bactericidal Concentration (MBC)

The tests were based on the technique of broth microdilution (ELOFF, 1998). Bacterial inoculation were standardized on 0.5 MacFarland's scale tube and diluted to 1:100. Aliquots $(10 \mathrm{~mL})$ of the dilution were distributed in 96 wells microtiter plates containing $100 \mathrm{~mL}$ of nutrient broth, obtaining approximately $10^{5} \mathrm{CFU} \mathrm{mL} \mathrm{m}^{-1}$, with posterior addition of the extracts. The extracts were diluted in concentrations between 10 and $320 \mathrm{mg} \mathrm{mL}^{-1}$. The plates were incubated at $37^{\circ} \mathrm{C}$ for a period of 18 to $24 \mathrm{~h}$. In order to evaluate the antibacterial activity, each well received $20 \mu \mathrm{L}$ of $0.5 \%$ triphenyl tetrazolium chloride, with reading being performed after one hour. MIC was identified visually and considered as the lowest concentration of the extract capable of inhibiting bacterial growth (SARTORATTO et al., 2004).

Determination of $\mathrm{MBC}$ was performed by inoculating $25 \mu \mathrm{L}$ of each dilution, with no apparent growth in MIC, in Brilliant Green Agar, with incubation $\left(37^{\circ} \mathrm{C}\right)$ for a period of 18 to $24 \mathrm{~h}$. The presence of colonies was considered a evidence of bacteriostatic action, while the absence of colonies indicated bactericidal activity. MBC was considered on the plate which presented no bacterial growth (BARBOSA \& TORRES, 1998). All tests were performed in duplicates.

\section{RESULTS AND DISCUSSION}

In vitro antibacterial activity evaluation

In the tested concentration, $85.7 \%$ of the extracts presented inhibitory activity against some serovar of Salmonella (Table 1). All serovars were susceptible to a minimum of five (25\%) and maximum of 11 extracts tested (55\%) (Figure 1).The six extracts that presented action against most of the serovars were the following ones: Punica granatum (Lythraceae), Achyrocline satureioides (Compositae), Eugenia jambolana, Eugenia uniflora, Caryophyllus aromaticus and Psidium araca (Myrtaceae) (Table 1). The extracts of Myrtaceae are among the five most active ones. The species of Myrtaceae and Lythraceae, belonging to the order Myrtales (BREMER et al., 2000; THE ANGIOSPERM PHYLOGENY GROUP, 2003) are genetically closely related, which could justify the similar behavior concerning inhibitory capacity.

Determination of Minimum Inhibitory Concentration (MIC) and Minimum Bactericidal Concentration (MBC) The seven extracts submitted to MIC and MBC presented bacteriostatic activity and six of them showed bactericidal activity. Due to technical problems some extracts were not tested (NT) against all serovars, as shown in table 2. The extract of Caryophyllus aromaticus presented higher antimicrobial activity for MIC and MBC (Table 2, Figure 2). NASCIMENTO et al. (2000) also confirmed the inhibitory activity of this species against $64.2 \%$ of the evaluated bacteria, including $\boldsymbol{S}$. Choleraesuis. Phytochemical composition performed by the authors detected the presence of eugenol, tannins and flavonoids, and tests with eugenol showed an inhibitory effect against S. Choleraesuis.

The antibacterial activity of Punica granatum was significant considering the bacteriostatic effect against all serovars (Table2, Figure2). Similar results

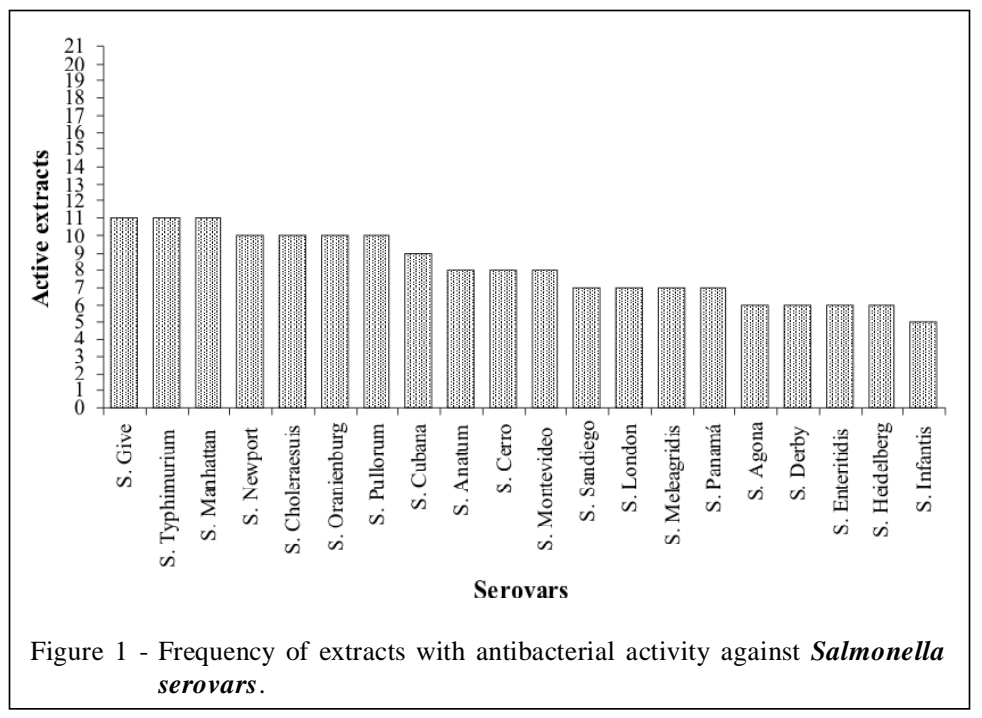

Ciência Rural, v.41, n.2, fev, 2011. 


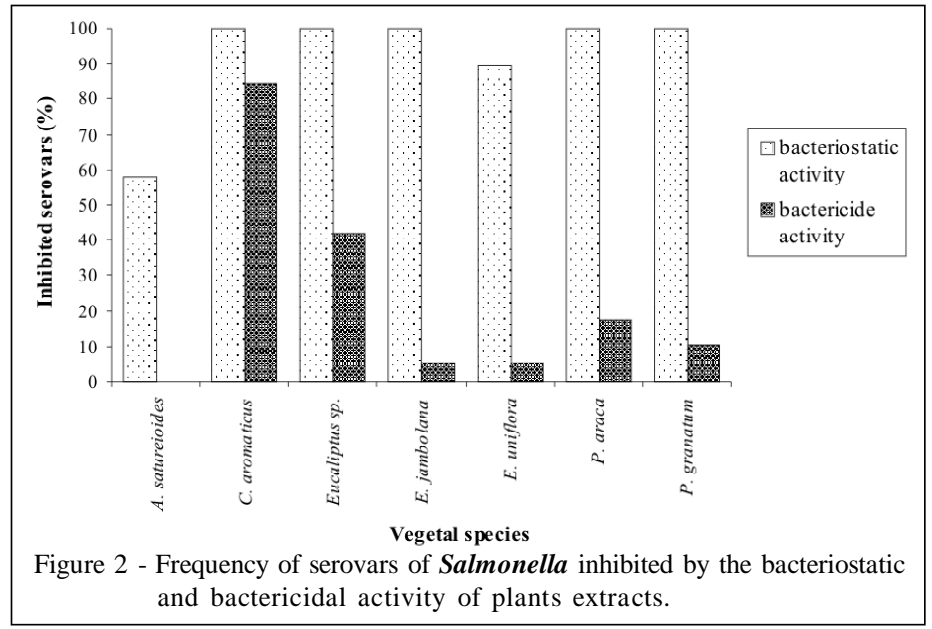

with this species were obtained by MICHELIN et al. (2005) against several organisms. The antimicrobial potential of Punica granatum has been verified against several bacteria species (HOLETZ et al., 2002; MACHADO et al., 2002; MICHELIN et al., 2005; NASCIMENTO et al., 2000; VORAVUTHIKUNCHAI et al., 2005), however, no data have shown such activity against Salmonella. MACHADO et al. (2002) attributed the antimicrobial activity to the presence of punicalagin.

The extract of Eucalyptus sp. presented inhibition against $100 \%$ of the serovars tested, showing bactericidal effect on $42.1 \%$ of them. FRANCO et al. (2005) reported antimicrobial activity of Eucalyptus cinerea against five distinct bacteria and attributed such activity to the presence of 1-8 cineol or eucalyptol in its essential oil. Psidium araca presented bacteriostatic activity against all serovars and bactericidal activity to $S$. Derby, $S$. Enteritidis and $S$. Manhatan. No similar report has been found, indicating the need for more studies with this extract.

Eugenia jambolana demonstrated bacteriostatic activity against all serovars and bactericidal activity only against $\boldsymbol{S}$. Pullorum. MICHELIN et al. (2005) described similar values for MIC, although against other bacterial species. LOGUERCIO et al. (2005) verified antimicrobial activity of $\boldsymbol{E}$. jambolana against 17 bacterial isolates, including S. Typhi. NASCIMENTO et al. (2000) confirmed the inhibitory activity against $57 \%$ of 14 microorganisms tested, but not against $\boldsymbol{S}$. Choleraesuis. Such variation in the activity of the plant extracts might be related to factors such as age, physiological state, part of the plant used, and season, which affects both the concentration and the metabolite groups present in the extracts (POSER \& MENTZ, 2004; RAVEN et al., 2007).
The extract of Eugenia uniflora was bacteriostatic against $89.47 \%$ of the serovars (Table 2). Substances such as flavonoids, sesquiterpenes, tannins, antocianic pigments, and saponins were identified in its composition (LORENZI \& MATOS, 2002). Tannins and saponins presented antimicrobial properties (LOGUERCIO et al., 2005; RAVEN et al., 2007; SANTOS \& MELLO, 2003; VORAVUTHIKUNCHAI, 2005). Achyrocline satureioides presents bacteriostatic activity against $61.1 \%$ of the serovars (Table 2). POLYDORO et al. (2004) assessed the inflorescences of this species and confirmed that the hydroethanolic extracts presented high levels of flavonoids, whose effect, however, only retarded the bacterial multiplication.

The efficacy of each extract varied for different serovars. While $\boldsymbol{S}$. London presented resistance to all extracts in MBC, $\boldsymbol{S}$. Pullorum was the most susceptible serovar (Table 2). This serovar is present only in avian species, while the others are adapted to several different hosts. Different susceptibility of the serovars is probably related to defense mechanisms, since it is well known that bacteria can develop protection mechanisms such as changes in the permeability and structure of the cell wall, production of inhibitory enzymes, and alteration of the molecules attacked by the antibacterial (TRABULSI \& ALTHERTHUM, 2005).

Some results obtained in the present tests to determine MIC and diffusion in agar doesn't have relation among each other does not present relationships with one another. Regarding the first, the best results were obtained with the extract of P. granatum, which inhibited all serovars. However, this result was not associated with the lowest MIC, which was obtained from the extract of $\boldsymbol{C}$. aromaticus. 
Similarly, some extracts, which were inactive in the agar diffusion test, presented activity in broth microdilution technique. This result is justified by the physicalchemical properties of the components of each extract, which could influence the diffusion of its components in the culture medium. Thus, in the case of plant extracts, the soleus diffusion in agar for assessing antimicrobial activity is not recommended. On the contrary, it can be used as orientation for selecting species with antimicrobial properties to determine the MIC and MBC, or even, to assess the results obtained in this study with the same sample.

\section{CONCLUSION}

The results obtained indicated that the vegetal extracts tested present potential antimicrobial activity with efficient properties in the inhibition of Salmonella, especially those from the Myrtaceae family. Such properties may be the object of further and specific studies for the identification and isolation of the active compounds or the assessment of their usefulness as therapeutic agents.

\section{ACKNOWLEDGEMENTS}

The authors want to thank for Fundo de Apoio a Pesquisa - FAP da Universidade do Contestado - UnC, Concórdia, $\mathrm{SC}$, for granting a scholarship to the first author. Laurimar Fiorentin (in memorian).

\section{REFERENCES}

AVANCINI, C.A.M. et al. Atividade bacteriostática e bactericida do decocto de Baccharis trimera (Less.), Compositae, carqueja, como desinfetante ou anti-séptico. Arq Bras Méd Vet Zootec, v.52, n.3, p.230-234, 2000. Available from: <http:// www.scielo.br/scielo.php?script $=$ sci_arttext\&pid $=$ S010209352000000300011\&lng=en\&nrm=iso>. Accessed: Mar. 27, 2006. doi: 10.1590/S0102-09352000000300011.

BARBOSA, H.R.; TORRES, B.B. Microbiologia básica. São Paulo: Atheneu, 1998. 196p.

BREMER, K. et al. Introduction to phylogeny and systematic of flowering plants. 6.ed. Uppsala: Uppsala University, 2000. 110p.

CHAGAS, A.C.S. Controle de parasitas utilizando extratos vegetais. Rev Bras Parasitol Vet, v.13, supl., p.156-160, 2004 .

CIRAJ, A.M. et al. Antibacterial activity of black tea (Camelia sinensis) extract against Salmonella serotypes causing enteric fever. Indian J Med Sci, v.55, n.7, p.376-381, 2001. Available from: <http://www.indianjmedsci.org/text.asp?2001/55/7/376/ 12062>. Accessed: May 27, 2006.

COELHO, A.M.S.P. et al. Atividade antimicrobiana de Bixa orellana L. (Urucum). Rev Lecta, v.21, n.1, p.47-54, 2003.
Available from: <http://www.saofrancisco.edu.br/edusf/ publicacoes/RevistaLecta/Volume_02/uploadAddress/lecta7\%5B6229\%5D.pdf>. Accessed: Jun. 07, 2006.

ELOFF, J.N.P. A sensitive and quick microplate method to determine the minimal inhibitory concentration of plant extracts for bacteria. Planta Med, v.64, n.8, p.711-713, 1998.

EUROPEAN AGENCY FOR THE EVALUATION OF MEDICINAL PRODUCTS - EMEA. Antibiotic resistance in the European Union associated with therapeutic use of veterinary medicines. London UK, 1999. 79p. (Report and Qualitative Risky assessment by the Committee for Veterinary Medicinal Products - CVMP-342/99).

FRANCO, J. et al. Composição química e atividade antimicrobiana in vitro do óleo essencial de Eucalyptus cinerea F. Mull. Ex Benth., Myrtaceae, extraído em diferentes intervalos de tempo. Rev Bras Farmacogn, v.15, n.3, p.191-194, 2005. Available from: $<$ http://www.scielo.br/scielo.php?script=sci_arttext\&pid=S0102695X2005000300004\&lng=en\&nrm=iso>. Accessed: Aug. 16, 2007. doi: 10.1590/S0102-695X2005000300004.

GROOVE, D.C.; RANDALL, W.A. Assay methods of antibiotics: a laboratory manual-antibiotics monographs, 2. USA: Medical Encyclopedia 1995. 80p.

HOLETZ, F.B. et al. Screening of some plants used in the Brazilian folk medicine for the treatment of infectious diseases. Mem Inst Oswaldo Cruz, v.97, n.7, p.1027-1031, 2002. Available from: <http://www.scielo.br/scielo.php?script=sci_arttext\&pid=S007402762002000700017\&lng=en\&nrm=iso>. Accessed: Aug. 16, 2007. doi: 10.1590/S0074-02762002000700017.

LOGUERCIO, A.P. et al. Atividade antibacteriana de extrato hidro-alcoólico de folhas de jambolão (Syzygium cumini (L.) Skells). Ciência Rural, v.35, n.2, p.371-376, 2005. Available from: <http://www.scielo.br/pdf/cr/v35n2/a19v35n2.pdf>. Accessed: Mar. $27,2007$.

LORENZI, H.; MATOS, F.J.A. Plantas medicinais no Brasil: nativas e exóticas. Nova Odessa, SP: Instituto Plantarum, 2002. 512p

MACHADO, T.B. et al. Antimicrobial ellagitannin of Punica granatum fruits. J Braz Chem Soc, v.13, n.5, p.606-610, 2002. Available from: <http://www.scielo.br/ scielo.php? script $=$ sci_arttext\&pid=S 0103 50532002000500010\&lng=en\&nrm=iso>. Accessed: Aug. 16, 2010. doi: 10.1590/S0103-50532002000500010.

MICHELIN, D.C. et al. Avaliação da atividade antimicrobiana de extratos vegetais. Rev Bras Farmacog, v.15, n.4, p.316320, 2005. Available from: <http://www.scielo.br/pdf/rbfar/ v15n4/a09v15n4.pdf>. Accessed: Mar. 23, 2007.

NASCIMENTO, G.G.F. et al. Antibacterial activity of plant extracts and phytochemicals on antibiotic resistant bacteria. Braz J Microbiol, v.31, n.4, p.247.256, 2000. Available from: <http://www.scielo.br/pdf/bjm/v31n4/a03v31n4.pdf>. Accessed: Set. 26, 2006.

POLYDORO, M. et al. Antioxidant, pro-oxidant and cytotoxic effects of Achyrocline satureioides extracts. Life Sci, v.23, n.74, p.2815-2826, 2004. Available from: <http:// linkinghub.elsevier.com/retrieve/pii/S0024320504001225>. Accessed: Set. 20, 2006. 
POSER, G.L.V.; MENTZ, L.A. Diversidade biológica e sistemas de classificação. In: SIMÕES, C.M.O. et al. (Orgs). Farmacognosia: da planta ao medicamento. 5.ed. Porto Alegre/Florianópolis: UFRGS/UFSC, 2004. p.75-89.

RAVEN, P.H. et al. Biologia vegetal. 7.ed. Rio de Janeiro: Guanabara Koogan, 2007. 728p.

SANTOS, S.C.; MELLO, J.C.P. Taninos. In: SIMÕES, C.M.O. et al. (Orgs). Farmacognosia: da planta ao medicamento. 5ed. Porto Alegre/Florianópolis: UFRGS/UFSC, 2003. p.615683.

SARTORATTO, A. et al. Composition and antimicrobial activity of essential oils from aromatic plants used in Brazil. Braz J Microbiol, v.35, n.4. p.275-280, 2004. Available from: 〈http://www.scielo.br/pdf/bjm/v35n4/v35n4a01.pdf〉. Accessed: Jul. 01, 2007.

SOUZA, C.A.S. et al. Atividade antimicrobiana de Tagetes minuta L. Compositae (chinchilho) frente a bactérias Grampositivas e Gram-negativas. Braz J Vet Res Anim Sci, v.37, n.6, p.429-433 2000. Available from: <http://www.scielo.br/ scielo.php? script =sci_art text\&pid=S 1413 95962000000600001\&lng=en\&nrm=iso>. Accessed: Aug. 16, 2007. doi: 10.1590/S1413-95962000000600001.
SOUZA, V.C.; LORENZI, H. Botânica sistemática: guia ilustrado para identificação das famílias de Angiospermas da flora brasileira, baseado em APGII. Nova Odessa: Instituto Plantarum. 2005. 640p.

THE ANGIOSPERM PHYLOGENY GROUP. An update of the Angiosperm Phylogeny Group classification for the orders and families of flowering plants: APG II. Bot J Linnean Soc, v.141, p.399-436, 2003.

TRABULSI, L.R.; ALTHERTHUM, F. Microbiologia. 4.ed. São Paulo:Atheneu, 2005. 718p.

VIEIRA, O.M.C. et al. Atividade antimicrobiana de Struthanthus vulgaris (erva-de-passarinho) Rev Bras Farmacog, v.15, p.149-154, 2005. Available from: <http://www.scielo.br/ scielo.php? script=sci arttext\&pid=S 0102 695X2005000200014\&lng=en\&nrm=iso >. Accessed: Aug. 16, 2007. doi: 10.1590/S0102-695X2005000200014.

VORAVUTHIKUNCHAI, S.P. et al. Inhibitory effects of active compounds from Punica granatum pericarp on verocytotoxin production by enterohemorrhagic Escherichia coli O157: H7. J Health Sci, v.51, n.5, p.590-596, 2005. Available from: <http://jhs.pharm.or.jp/51(5)/51_590.pdf >. Accessed: Set. 23, 2006. 